\title{
Impact and Control of the Range Crane Fly (Tipula simplex Doane) in the Central Valley of California
}

\author{
MARGARET J. HARTMAN AND C. LYNN THOMAS
}

\begin{abstract}
The larvae of the range crane fly (Tipula simplex) are responsible for extensive damage to rangeland of the central valley of California, but the damage occurs infrequently in years when there are extremely high densities. These outbreaks appear to be due to favorable climatic conditions during the early larval instars. Means of biological (including pheromone), mechanical, fire, and chemical control are discussed. Early detection is a key in minimizing damage.
\end{abstract}

The California a nnual rangeland provides substantial quantities of forage for cattle during fall, winter, and spring. Annual grasses and forbs dominate this range type. Vegetation starts growing with the advent of fall and winter rains, usually maturing by April or May in some years.

An event which coincides with the fall rain is the breaking of diapause and eventual hatching of the eggs of the range crane fly (Tipula simplex Doane). The range crane fly is one of the most destructive species to rangeland in California (Essig 1958). It has a known California distribution from northern Santa Cruz County, north to Marin County, and east to Sacramento County. A second, discontinuous population is found in the Yokohl Valley of Tulare County (Alexander 1967). During the winter of 1977-78, a third

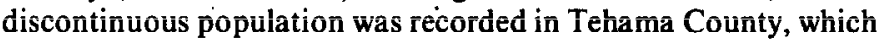
was confirmed by the authors (Fig. 1). Unconfirmed reports indicate that the range crane fly may also occur in Oregon, east of the Cascade Mountains. In California, the suitable habitat appears to be the unirrigated pastures of the central valley of California, below the oak-woodland zone.

Crane fly larvae feed on decaying matter in the soil, cowpads which are at least one season old, and roots of range forage plants. Infrequently (about once every 6 years in Tulare County), the larvae reach such high concentrations that they destroy all forage, denude hills, and cause adverse effects on the watershed (Fig. 2). This condition has in the past been confused with localized overgrazing.

The present paper reports on the effects of the range crane fly on rangeland in Tulare County, California, and possible control measures.

\section{Study Area and General Methods}

The study area in Yokohl Valley is located approximately $11 \mathrm{~km}$ southeast of Exeter, California. Elevation ranges from 150 to 305 $\mathrm{m}$ above sea level. Topography is rolling with many small drain-

Authors are with the Biology Department, California State University, Los Angeles 90032, and the Tulare County Agricultural Commissioners Office, Visalia, Calif. 93277.

The authors would like to thank the Boston Land Company and CSULA for financial support of this project, and Mr. William Clark and Dr. Robert Zahary for their comments on the project and their critical reading of the paper. We would also like to thank L. Gholson, C.D. Hynes, N. Mosman, and J. Surfleet for their collaboration in various aspects of data gathering and analysis.

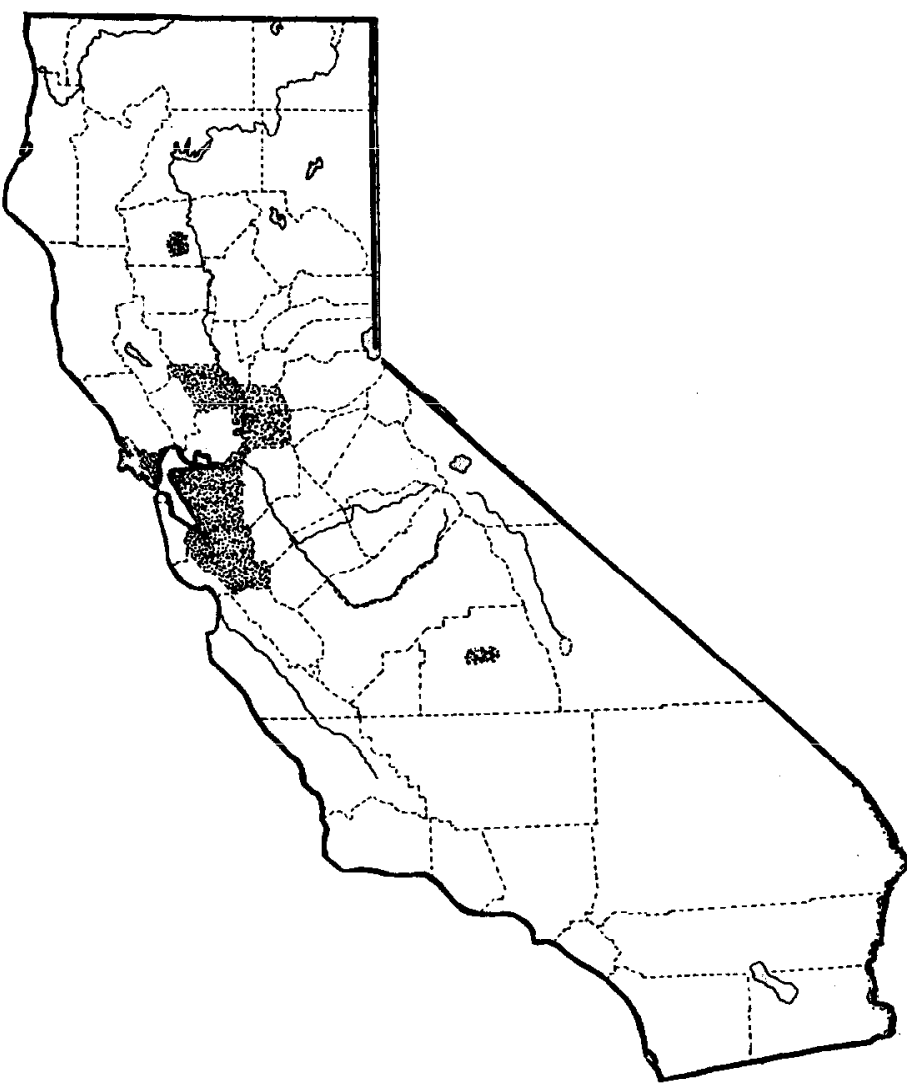

Fig. 1. Range of Tipula simplex in California.

ages dissecting the area. The overall study area is generally on level-to-gently sloping alluvial soils with the slope usually not exceeding 5 to $6 \%$.

Soils of the area are both alluvial and upland (Storie et al. 1940) derived dominantly from basic igneous parent material with the upper surfaces displaying slightly acidic qualities.

Annual precipitation ranges from $304 \mathrm{~mm}$ to $633 \mathrm{~mm}$ with $85 \%$ occurring between November and April (State of California Department of Water Resources, 1955-60). The mean annual ambient temperature is $16^{\circ} \mathrm{C}$ with extremes ranging from $8^{\circ} \mathrm{C}$ to $47^{\circ} \mathrm{C}$ (U.S. Weather Bureau, 1960-76).

Four sites were studied. Two sites were relatively flat, the third site was a hillside with a southern exposure, and the fourth was a hillside with a northern exposure. All sites have similar vegetation 


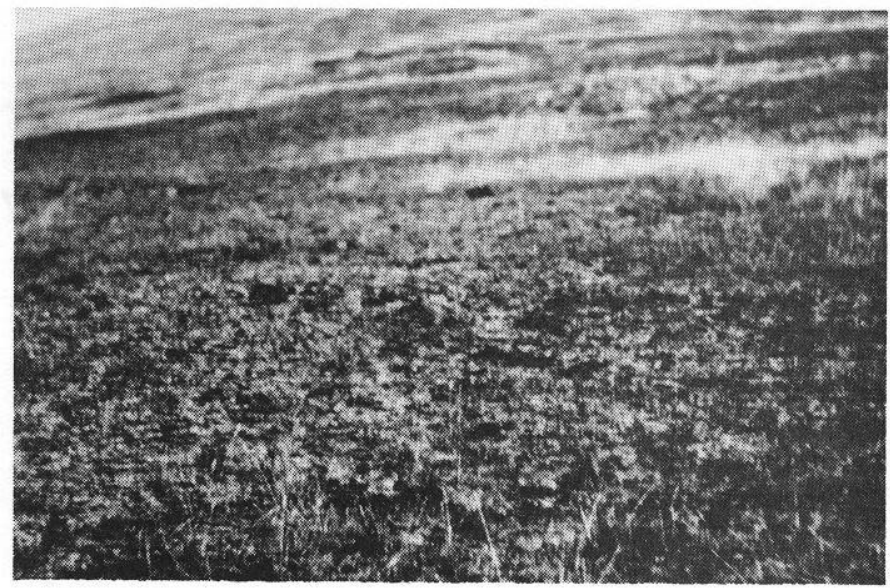

Fig. 2. Damage to pastureland from outbreak densities of Tipula simplex.

types. Those species found on the study site during the first rains in September (usually $12 \mathrm{~mm}$ or less) were turkey mullein (Eremocarpus setigerus Benth), blue curl (Trichostema lanecolatum Benth.), and tarweed (Hemizonia kelloggii Greene). Second rains, in late October and early November, brought on the annual grass cover. This type was dominated by wild oats (Avena fatua L.), but is closely rivaled by several Bromus species, chiefly foxtail chess (Bromus rubens L.), soft chess (B. mollis L.) and rip-gut brome ( $B$. diandrus Roth). Forbs are of secondary importance, though the number of plants occurring in the area is large. From a grazing viewpoint, bur clover (Medicago polymorpha L.) and filaree (Erodium cicutarium (L) L'Her.) and E. botrys (Cav.) Bertol. are important constituents and furnish abundant forage. (Nomenclature used was that of Munz 1968.)

The adults of the range crane fly emerge in late winter or early spring, depending upon the winter temperature. Copulation occurs almost immediately, and may last for 24 hours. The eggs are laid within 3 days in the soil and immediately enter a dormant period (diapause). Diapause is broken by the onset of rain in September or October, but the embryos undergo a second dormancy period (quiescence), and finish development and hatch after the onset of the second series of rains (Hartman and Hynes 1977).

The larvae have four instars. Late second instar, third, and fourth instar larvae have a clumped distribution, being much more numerous under cowpads than in the grass. This is due in part to the action of a locomotory inhibiting pheromone (Hartman, et al. 1978).

The molt from larvae to pupa occurs during mid to late February. All larvae pupate within 10 days of each other; adult emergence occurs in the field about 2 weeks after the first pupa appears. Males emerge before females (Hartman and Hynes 1977).

The technique used for sampling populations of the range crane fly required 3 estimates. Density of crane flies under cowpads ( $\mathrm{n}=$ 25 ) was estimated by counting numbers of larvae in and under the pads. Density of crane flies in grass was estimated by removing a known diameter circle of soil $(n=25)$ to a depth of two inches and counting all the larvae in the grass and soil in the field. Density of the cowpads was estimated by nearest neighbor method. The population estimate was:

$$
\begin{aligned}
\text { density }=a(b / 100)+c \quad \frac{(100-b)}{(100)} \quad \begin{array}{l}
\text { where } \\
a
\end{array} & =\text { density of crane flies in cowpad } \\
b & =\text { density of cowpads } \\
c & =\text { density of crane flies in grass }
\end{aligned}
$$

This technique appears to be cumbersome, but several other techniques which have proven successful for estimating densities of other species of crane flies were attempted on this species with no success. At night the larvae of other crane flies come to the surface to feed (Wilkinson and MacCarthy 1967), but the larvae of the range crane fly do not. Tipula paludosa larvae will come to the surface in response to ortho-dichloro-benzene (Barnes 1941). This is ineffective on the range crane fly.

\section{Results}

\section{Density and Damage}

From year to year (1974-1977) and from pasture to pasture, crane fly density was recorded from 0 larvae $/ \mathrm{m}^{2}$ to 300 larvae $/ \mathrm{m}^{2}$. During that time, there was no measurable effect on the amount of forage. However, when larval density exceeded $3,000 \mathrm{larvae} / \mathrm{m}^{2}$, as it did in 1972 and 1973, the effect on the forage was devastating (Fig. 2).

In the last outbreak in Tulare County (1972-73), 160 ha of rangeland were denuded. The yield of that rangeland was reduced the next year also, requiring reduction of the stocking rates and supplementation of forage. Considering the expense of attempted control by pesticide, decrease in the profits due to a decreased stocking rate, and increased expense due to the cost of supplemental feed, we calculated that the loss for the 2 years was estimated at $\$ 90,000$.

\section{Control Measures}

\section{Biological Control}

Birds are the most visible biological control. Starlings (Sturnus vulgaris L.), red-winged blackbirds (Agelaius phoeniceus (L), killdeer (Charadrius vociferus L.), and long billed curlews (Numenius americanus Bechstein) are among the species that have been seen to eat the larvae of the range crane fly. The birds usually come through an infested area about the time that the larvae are pupating. All the birds feed on larvae in or under cowpads during nonoutbreak years, feeding either by poking their beaks through the cowpad or by flipping the cowpad and feeding on the larvae which are then exposed. Although both larvae and pupae are present under the cowpad, the birds were never observed eating pupae, only the larvae.

Since cowpads only cover one percent of a field, and birds feed only on those larvae in or under cowpads, we feel that bird predation is an ineffective means of population regulation. In addition, bird predation occurs at the time when the larvae are pupating, and by then the crane flies have done their damage.

We have not observed any larval deaths in the field or the laboratory that could be attributed to parasites or pathogens. A study done in England on the marsh crane fly, found that viruses, microsporidia, and bacteria are found in larvae in the field, and are lethal. They also found other parasites which did not kill the larvae, but did reduce their fecundity (Carter 1976). Introduced parasites or pathogens might prove effective means of population regulation in the future.

\section{Self Regulation}

Most insects have a self regulation system of population control. As the number of individuals increases and competition for food increases, the number of offspring which a female produces decreases. Eventually, the insect population comes into balance with its environment.

In the range crane fly, we studied field captured females from a number of a reas ranging in density from one per $\mathrm{m}^{2}$ to 800 per $\mathrm{m}^{2}$. A correlation coefficient was calculated to determine the relationship between the density of the females and the number of eggs laid per female (Table 1). It appears that crowding plays no part in regulating population numbers at low to moderate densities.

Table 1. Regression Analysis of Female Density and Eggs Laid Per Female.

\begin{tabular}{ll}
\hline \hline Characteristic & Value \\
\hline$R$ & $-.233772^{1}$ \\
$R^{2}$ & $-.0546518^{1}$ \\
Slope & $-.007475146^{1}$ \\
\hline
\end{tabular}

${ }^{1}$ Significance $=$ n.s. 


\section{Weather}

In the laboratory, temperature, photoperiod, and moisture have statistically significant effects on the hatching success (Hartman and Hynes 1980). However, no correlation exists between years of high crane fly densities with years of weather favorable for hatching.

\section{Pheromones}

The only pheromone which has been isolated so far is a larval locomotory inhibitor (Hartman, et al. 1978). The only known way that a locomotory inhibitor can be used as a control is if it can be used to make a rapidly moving insect stay in an unfavorable environment, or stay in contact with a pesticide. The range crane fly larva is a slow moving insect, so the addition of a locomotory inhibitor to pesitcide will have little additional benefit.

\section{Irrigation}

The eggs have a very low survival rate if kept damp all summer, or if there is no natural drying period between the first and second rains (Hartman and Hynes 1980). Irrigation would climate the range crane fly problem, but the expense would be prohibitive.

\section{Sanitation}

A possible means of control, suggested by ranchers, is to break the cowpads mechanically. Since the crane fly larvae aggregate under cowpads, this would destroy their preferred habitat, and should decrease their numbers. However the number of larvae inhabiting cowpads is roughly $10 \%$ of the total population. Breaking up cowpads will affect a small proportion of the larvae, which could live equally well in the grass. In addition, these would be the same individuals which are presently destroyed by existing biological control measures.

\section{Fire}

Fire during the summer may affect the crane fly eggs. Although fire itself does not increase soil temperature where the eggs are located, the lack of straw in the field will increase the soil's exposure to the sun and daily soil temperature will be higher in burnt fields than in unburnt fields. Laboratory evidence indicates that a high temperature leads to lower egg survival (Hartman and Hynes 1980). However, field tests are still needed to confirm the effectiveness of a slightly warmer soil on egg mortality.

The loss of ground cover by fire, even if it were successful in reducing the number of crane fly eggs which hatch, has deleterious side effects. The range is more susceptible to soil erosion and the winter seedlings are more susceptible to frost.

\section{Chemical Control}

Sixteen different trials were conducted by the U.C. Davis Entomology Department and the Tulare County Agricultural Extension Service. Plots were treated in 1971 (4 replicates per treatment) and 2 samples from each replicate were examined 3, 10, and 17 days after treatment. Most effective in immediate and long-term control were: methyl parathion ( $485 \mathrm{~g} / \mathrm{l} \mathrm{E.C.} \mathrm{at} \mathrm{the} \mathrm{rate} \mathrm{of} 561 \mathrm{~g} / \mathrm{ha}$ ), ethyl parathion $(485 \mathrm{~g} / \mathrm{l} \mathrm{E}$.C. at the rate of $561 \mathrm{~g} / \mathrm{ha})$, and Sevin $(485 \mathrm{~g} / 1$ Flow at the rate of $2,244 \mathrm{~g} / \mathrm{ha}$ ) (Lange et al. 1971).

\section{Predicting Outbreaks}

After 5 years we can say for certain that there is not a gradual increase of range crane fly population numbers year after year in an area until the population reaches outbreak densities. We have identified 3 possibilities which explain periodic outbreaks: adult females lay many more than the usual number of eggs in the spring before the outbreak year; the same number of eggs are laid, but a much larger number of them hatch the fall of an outbreak year; survival of early larval instars is greatly enhanced in an outbreak year. In central Tulare County (the only county for which this test has been run), we found four climatic factors which were significantly different in outbreak years than in nonoutbreak years. They are (listed in descending order of importance):
1. Total larvae in December averages $8.8 \mathrm{~cm}$ in outbreak years, and only $3.7 \mathrm{~cm}$ in nonoutbreak years.

2. The average minimum temperature in November in outbreak years is $4.1^{\circ} \mathrm{C}$ and $5.3^{\circ} \mathrm{C}$ in nonoutbreak years.

3. The average precipitation in November is $3.1 \mathrm{~cm}$ in outbreak years, and $5.7 \mathrm{~cm}$ in nonoutbreak years.

4. The average maximum temperature in December is $10.8^{\circ} \mathrm{C}$ in outbreak years and $12.4^{\circ} \mathrm{C}$ in nonoutbreak years.

For Tulare County, we can be $85 \%$ sure that a range crane fly outbreak will occur if December's rainfall is higher than average, minimum temperature in November is cooler than a verage, rainfall in November is below average, and maximum temperatures in December are below average. November and December are the months in which the early larval instars are found, which causes us to more strongly support our third possible hypothesis, that outbreak years occur when there is a high survival of early larval instars.

\section{Recommendations for Timing of Control}

The most important aspect of control is that it is done early. As soon as forage crops have sprouted, begin checking under cowpads. If there are large numbers of crane fly larvae under the cowpads, dig up several grassy areas measuring $0.1 \mathrm{~m}^{2}$ down to the roots and count the number of larvae in the sample. If there is an average of 200 larvae in each sample, you will have extensive damage in that field in that year. The sooner that the treatment is initiated after the crane fly larvae are observed in these densities, the less damage will be sustained. If the larvae are less than an inch in length, then they will continue to eat the forage for 3 to 4 weeks. If the control measures are delayed until the larvae are longer than an inch, or until damage to the forage is observable, then the larvae will probably continue to feed for only 1 to 2 weeks, and of course, control measures will be less effective in minimizing forage loss. If the environmental factors which signal an outbreak year are known in an area, as are presently known in Tulare County, early, more effective control operations can be initiated. Counties in the areas which have had outbreaks of range crane fly should test their own weather data for outbreak versus nonoutbreak years, and determine their own predictive weather factors.

\section{References Cited}

Alexander, C.P. 1967. The crane flies of California. Bull. Calif. Insect Surv. Vol. Univ. Calif. Press, Berkeley, and Los Angeles. 269 p.

Bames, H.F. 1941. Sampling for leatherjackets with orthodichlorobenzene emulsion. Ann. Appl. Biol. 2 8:23-28.

Carter, J.B. 1976. A survey of microbial, insect, and nematode parasites of Tipulidae (Diptera) larvae in north-east England. J. Appl. Ecol. 13:103-122.

Essig, E.0. 1956. Insects and mites of Western North America. MacMillan $1050 \mathrm{p}$.

Hartman, M.J., and C.D. Hynes. 1977. Biology of the range crane fly Tipula simplex Doane. Pan. Pac. Entomol. 53:118-123.

Hartman, M.J., and C.D. Hynes. 1980. Environmental factors influencing hatching of Tipula simplex eggs (Diptera;Tipulidae). Pan. Pac. Entomol. 56:268-272.

Hartman, M.J., J.A. Surneet, and C.D. Hynes. 1978. Aggregation pheromones in the larvae of Tipula simplex eggs (Diptera:Tipulidae). Pan Pac. Entomol. 54:305-310.

Munz, P.A. 1968. A California Flora. University of California Press, Berkeley and Los Angeles. $1681 \mathrm{p}$.

State of Califomia, Department of Water Resources. Kaweah River Flows, Diversions and Service Areas, State of California 1955-60.

Storie, R.E., B.C. Owen, E.J. Carpenter, M.H. Layton, and W.J. Leightly. 1940. Soil Survey of the Visalia Area, California, USDA. Bureau of Plant Industry Series 1935. No. 16.

U.S. Weather Bureau. Climatological Data. California. Vol. 64-80.

Wilkinson, A.T.S., and H.R. MacCarthy. 1967. The marsh crane fly, Tipula paludosa $\mathrm{Mg}$, a new pest in British Columbia (Diptera:Tipulidae). J. Entomol. Soc. British Columbia 64:29-34. 